\title{
The Contribution of Postgraduation-Lato Sensu-At Distance for Training Health Field Professionals: A Case Study at a Brazilian Federal University
}

\author{
Márcia Gorett Ribeiro Grossi ${ }^{1}$, Salete Maria de Fátima Silqueira ${ }^{2}$, Laryssa Cristina Castro Gomes ${ }^{3}$, Lívia de \\ Cássia Silva ${ }^{3} \&$ Angela Maria Bissoli Saleme ${ }^{4}$ \\ ${ }^{1}$ Department of Education, Federal Center for Technological Education of Minas Gerais, Belo Horizonte, Brazil \\ ${ }^{2}$ Department of Basic Nursing, Federal University of Minas Gerais, Belo Horizonte, Brazil \\ ${ }^{3}$ AVACEFETMG search group, Federal Center for Technological Education of Minas Gerais, Belo Horizonte, \\ Brazil \\ ${ }^{4}$ Department of Education State Secretariat of Science and Technology of Espirito Santo, Vitória, Brazil \\ Correspondence: Márcia Gorett Ribeiro Grossi, Department of education, Federal Center for Technological \\ Education of Minas Gerais, Belo Horizonte, Brazil. Tel: 55-319-8335-7367. E-mail: marciagrossi@terra.com.br
}

Received: May 8, 2017 Accepted: June 11, $2017 \quad$ Online Published: September 28, 2017

doi:10.5539/ies.v10n10p29 URL: https://doi.org/10.5539/ies.v10n10p29

\begin{abstract}
This article aimed to verify the opinions of health professionals who are looking for distance learning courses offered by distance learning. In order to do so, a case study was carried out in 2017 at the Federal University of Minas Gerais (UFMG), specifically in a course offered in the distance modality by the Nursing School: "Specialization Course Pedagogical Training in Professional Education in the Health Area : Nursing "(CEFPEPE). The data collection instrument was a questionnaire made available online for the former students who had taken the offered course. The results show the nurses' concern about their permanent and continuous training to better serve the population. It was also realized that distance education contributes to health in Brazil, allowing professionals who are far from the metropolis and / or who do not have time to attend in-class course to undertake training. In addition, having access to new knowledge might improve the professional performance.
\end{abstract}

Keywords: distance education (EaD), lato sensu postgraduation, nursing

\section{Introduction}

Distance Education $(\mathrm{EaD})$ has been the fastest growing teaching modality in Brazil, as can be seen from the data of the $\mathrm{EaD}$ in Brazil (CensoEaD.br, 2014 and 2015), prepared and distributed by the Brazilian Association of Distance Education (ABED). According to the report, the EaD courses in 2014 reached 3868706 enrollments, of which $519839(13 \%)$ are enrolled in fully regulated courses, $476484(12 \%)$ in the semi-face regulated courses or EaD subjects from in-class courses, and 2872383 (75\%) in free courses. These numbers increased in 2015, as CensoEaD.br (2015: 46) shows. The report points out that the "[...] registration of enrollments revealed that the EaD moves at least 5048912 students in the most varied areas of knowledge, academic levels and types of courses." Therefore, there was an increase of more than 30.5\% over the period (2014-2015).

However, EaD is not a new teaching modality, but it has gained prominence with the advent of the internet and its expansion may also be justified by the understanding of the possibilities that this modality of teaching brings. Bisol (2010) believes in the importance of $\mathrm{EaD}$ as a new model of thinking about teaching and learning, and as a result of social, cultural and technological development of the world.

One aspect of significant relevance is that distance learning through the internet is very diverse, being present in several areas of knowledge, both in the initial formation of the professional and throughout one's life. In this research, the focus of interest was on health, due to its unquestionable importance to society. EaD might be a viable alternative for professionals in this area who are far from big centers and even those who do not have time to attend in-class courses to continue their studies and to improve themselves professionally through continuous education. Thus, Marques, Miranda, Moeira, and Riani (2012) consider that:

The operationalization of the education process is one of the challenges faced by managers and 
health professionals themselves. Several factors can be related to the difficulties encountered in the implementation of permanent education programs, among which the access to training and training centers stands out, considering the distance that can exist between these and the professionals. In this sense, the development of $\mathrm{EaD}$ programs has been an effective alternative in access to education at different levels and contexts (Marques et al., 2012: 72).

On the health area, CencoEaD.br divides it into two: Health Sciences and Environment and Health and presents the following data about these areas: in 2014, there were 87 courses offered entirely at a distant and, although in 2015 Census the number has decreased (65 courses), the enrollment has increased from 12060 to 21716 enrollments.

It is also worth mentioning that, according to the National Council of Scientific and Technological Development $(\mathrm{CNPq})$, the broad area of knowledge Health Sciences encompasses ten areas of knowledge: Medicine; Dentistry; Drugstore; Nursing; Nutrition; Collective Health; Phonology; Physiotherapy; Occupational Therapy and Physical Education. Nursing is the focus of interest of this article.

Regarding education levels, in 2014, the same Census presents a diversity of one thousand eight hundred and forty courses offered entirely from a distance. The majority of them $(42.33 \%)$ are the Lato Sensu Graduate (also called Specialization). This result was repeated in 2015, in a total of two thousand and six hundred and one courses offered entirely at a distant, and the majority (41.48\%) was latu sensu Post-Graduation.

Before this reality, it was decided to develop a research with the aim of verifying the opinions of health professionals who are looking for distance learning courses offered at a distant for qualification. In order to do so, a case study was carried out in 2017 at the Federal University of Minas Gerais (UFMG), specifically in a course offered in the distance modality by the Nursing School: "Specialization Course Pedagogical Training in Professional Education in the Health Area : Nursing "(CEFPEPE).

\section{In Light of Theory}

\subsection{Distance Education}

$\mathrm{EaD}$ is not a new teaching modality, it has been happening for many years, but with different peculiarities from the way it is known today. According to Nunes (1998), it might be said that distance education began with Plato's letters and the epistles of Saint Paul, followed later by experiences of education through correspondence in the late seventeenth century. From the middle of the nineteenth century, it had a wide development. For this reason, Moore \& Kearsley (2007) point out that EaD has evolved over five generations, which coexisted until the present days, and this evolution is identifiable by the main communication technologies, as can be seen below:

- 1st generation: it began in the 1880s, due to the creation of more accessible postal services that provided a more individualized education supported by correspondence study.

- 2nd generation: began in the twentieth century, due to the emergence of radio and television, adding the oral and visual dimensions.

- 3rd generation: it began in the late 1960s, characterized by the emergence of open universities, integrating audio/video and correspondence with face-to-face orientations.

- 4th generation: started in the 1980s, with the help of the computer, teleconferences were used for real-time student interaction with students and instructors.

- 5th generation: with the development of computers in 1975 and the internet in 1993 a generation of online virtual classes emerged. EaD is already applied worldwide, with collaborative learning on a single communication platform.

Therefore, it was with the popularization of Digital Technologies of Information and Communication, especially the internet and the virtual learning environments that the $\mathrm{EaD}$ has been gaining prominence in the educational scenario. In Brazil, the process of solidification of EaD began with the Law on the Guidelines and Bases of National Education (LDBN) no 9 394, dated December 20, 1996, and with Decree No. 5 622, dated December 19, 2005, which regulates Article 80 of the LDBN.

The clearest definition of EaD was made by Moran (2002), who defines it as the process of teaching and learning, mediated by technologies, where teachers and students are spatially and / or temporally separated. Moore \& Kearsley (2007) add that, because students and teachers are in different locations, they depend on some kind of technology for the transmission of information and interaction between students, teachers, tutors and the institution. 
Moran (2002) also believes that because of the characteristics of the $\mathrm{EaD}$, it is more suitable for adult learners, as they already have experience with individual learning. Another aspect of this type of teaching is that to study the student needs the motivation that, according to Bock (1999), is of paramount importance to the teaching and learning process, mainly because one of the motivations that lead people to look for courses at distance is the need to continue their studies, either to obtain a diploma or to qualify when already trained.

In fact, continuing education, which takes place in the process of constant formation, to always learn, to learn in service, joining theory and practice, reflecting on one's own experience, expanding it with new information and relationships (Moran, 2002).

According to Lopes and Grossi (2014), there are several possibilities that this modality of teaching offers. Its inclusive and democratic character not offering space-time barriers, it welcomes all students, regardless of their differences. In addition, the EaD can attend different educational levels from free courses, from short duration to the Lato Sensu Postgraduation. Reflecting on the comprehensiveness of the $\mathrm{EaD}$, it might be seen that it addresses several areas of knowledge, among them, health, issue of interest in this research. Thinking about health capacity building in $\mathrm{EaD}$ is to propose a new form of learning (Quaglia, Oliveira \& Velho, 2015). The authors themselves state:

$\mathrm{EaD}$ is an instrument that can aggregate (in) the training of health workers, regardless of their place of work. This type of teaching can give these professionals a new concept of learning. In this sense, we can consider through the analysis that the training in health in distance education (EaD) enables and enhances the learning of professionals working in the health area (Quaglia et al., 2015, p. 110).

The authors continue to argue that "EaD constitutes a resource that favors the teaching-learning process, in which strategies are developed to access virtual learning environments that allow for continuous training in health" (Quaglia et al., 2015, p. 110).

As already mentioned in this study, among the courses offered at a distance, Lato Sensu Postgraduate courses represent the highest level of education in Brazil in recent years. Perhaps due to the demands of the labor market that requires more qualified professionals in a specific subject of actuation or more practical modality of an area of knowledge, in addition to having a shorter duration than strictu sensu postgraduation courses. Thus, a consultation was carried out on the website of the Ministry of Education (MEC) in January 2017 to identify institutions offering fully distance courses in the area of Health. It was found out 52 public and private institutions, and 148 courses were identified.

\subsection{Teacher Training in the Health Area: Some Considerations}

The concern with the health system in Brazil began to be noticed in the 1970s, through the Brazilian Health Reform that proposed to society "a change in the organization of the current health system", as stated by Batista and Gonçalves (2011, p. 885). Still following the authors:

The VIII National Health Conference and the creation of the National Health Reform Commission in the 1980s were important for the many achievements that took place in the process of reorganizing the health system in Brazil. Despite many conflicts, clashes and different interests, important changes occurred, reaching the Brazilian Federal Constitution of 1988, which recognizes health as a right of all citizens and a duty of the State, and the creation of the Unified Health System (SUS) (Batista \& Gonçalves, 2011: 885).

Thus, in 1990, with the implementation of the SUS, as the authors point out, it began to organize a public system, with common principles and guidelines throughout the country, following the approval of the Organic Health Law in 1990 However, health care is still urgent and there are many challenges, as Batista and Gonçalves (2011) warn. For these authors:

The specialization of health care, the distance of the subject in the processes of care and the great differences between what the users think and the workers and health managers have been configured as a great tension in the construction of the dreamed health model, arriving, some Reducing users' access to the system or their exclusion (Batista \& Gonçalves, 2011: 885).

Thus, in 1990, with the implementation of the SUS, as the authors point out, it began to organize a public system, with common principles and guidelines throughout the country, following the approval of the Organic Health Law in 1990 However, health care is still urgent and there are many challenges, as Batista and Gonçalves (2011) warn. For these authors: 
The specialization of health care, the distance of the subject in the processes of care and the great differences between what the users think and the workers and health managers have been configured as a great tension in the construction of the dreamed health model, sometimes, reducing users' access to the system or their exclusion (Batista \& Gonçalves, 2011, p. 885).

Further, article 200, of the Brazilian Federal Constitution of 1988, in its section III, attributes to the SUS the competence to order training in the area of Health (BRASIL, 1988). It should also be considered that, according to the "Basic Operational Standard on Human Resources of the Unified Health System (NOB-RH/SUS), quality health care requires training of individual and collective attention "(Peres \& Ciampone, 2004, pp. 263-264).

In fact, it is necessary to understand that the health services have the necessary quality for the good service to the population. In this way, it is necessary to think about the training and qualification of the professionals who work in this area. Marques et al. (2012, p. 92) complement this idea when they affirm that "the adoption of permanent education strategies and programs is a fundamental element in the organization of health care." The same authors also state that permanent education programs are important for both the professional and the user, who receive the care. In addition, it is through continuing education that continuing education becomes effective. This idea is evidenced in Ceccim (2005):

(...) Continuing Education, when it belongs to the objective construction of institutional frameworks and to the endowment of careers by service in a specific time and place. It can also correspond to the Formal Education of Professionals, when it presents itself largely porous to the multiplicities of the reality of professional experiences and places itself in an alliance of integrated projects between the sector / world of work and the sector / world of education (Ceccim, 2005: 162).

Worth mentioning, the permanent education in health, as asserted by Ceccim and Ferla (2016), is problematizing teaching and meaningful learning. It is a SUS strategy for the training and development of health workers, which was debated and approved at the XII National Health Conference and the National Health Council (CNS) as a specific policy in the interest of the national health system (Ceccim \& Ferla, 2016).

However, the operationalization of the process of permanent education is one of the challenges faced by managers and health professionals themselves (Marques et al., 2012) due to several factors, such as the lack of time for professionals who cannot match work with the studies. Therefore, $\mathrm{EaD}$ emerges as an alternative for professionals to continue their studies, to upgrade or to qualify through courses such as, for example, lato sensu postgraduation at a distance, due to their flexible hours and to the fact that the courses focus on the practical areas of each profession.

Among the professionals in the health area, in this research stand out the graduates in Nursing who have a great diversity of performance, both in the academic area and in the labor market. According Barbosa et al. (2004, p. 10), Nursing is a profession that has a significant contingent of professionals working in several places and developing the most varied functions within the health area. For the authors, this profession is the main axis to support any health policy that aims at quality care.

Barboza (2016) reinforces this idea when he draws attention to the importance of Nursing in the national context. However, the author highlights the difficulties of nurses to study, such as the service scale (irregular distribution of schedules), excessive workload (needs to maintain two jobs to achieve a better standard of living) and the heavy work itself in the aspects Physical and emotional. The author also highlights the little time left for those professionals who need to share their attention with family, home care, leisure and rest. Therefore, the EaD with its flexible schedules and study shifts may be an alternative for these professionals to be able to continue their studies and to qualify through distance specialization courses.

\subsubsection{Specialization Course in Pedagogical Training in Professional Education in the Health Area: Nursing}

The UFMG Nursing School, besides offering undergraduate and postgraduate courses stricto sensu, also offer three Specialization Courses: Pedagogical Training in Professional Education in the Health Area; Nursing in Medium and High Complexity that covers five hospital areas, namely: Nursing in Cardiology and Hemodynamics, Nursing in Stomatherapy, Nursing in Organ and Tissue Donation and Transplantation, Nursing in Palliative Care, Nursing in Intensive Care and Obstetric Nursing / "Cegonha" (Stork) Network.

In this research, It was opted to work with the Specialization Course in Pedagogical Training in Professional Education in the Health Area: Nursing (CEFPEPE), since it is the oldest course (it has been offered since 2008) and is the only one offered at the distance mode. As reported on the website of the Center for Support Distance Education (CAED), Administrative Unit of the Pro-Rectorate of Graduation (Prograd/UFMG) linked to the 
Directorate of Distance Education, the course is designed to:

- qualify health professionals to use pedagogical approaches in the daily life of their work in the perspective of promoting health by producing better health indicators;

- qualify health professionals for adequate performance in the medium-level health training processes;

- lead the health professionals for an effective permanent health education; developing studies that enable better use of information and communication technologies in educational processes, aiming at increasing the coverage of the training of health professionals.

It is important to point out that this course had this name (CEFPEPE) from 2008 to 2013, due to this name has been used until this date as (CEFPEPE). From 2014 on, the course was offered to health professionals covering the 14 health areas and it was created a new name: CEFPEPS.

Thus, CEFPEPE was offered in several in-house support poles distributed in eleven towns in the countryside of Minas Gerais - Brazil. In each year, the Course had the support Pole in one of these eleven towns, although in some years the course had several Poles acting at the same time. The course had a workload of 660 hours distributed in three periods, one of the requirements for the student to obtain the certificate was the presentation of a Course Completion Work (TCC). The organization of their curriculum is constituted by the theoretical bases offered, which represent the selection of knowledge to beyond what to teach, also considering the reason for teaching, as can be observed in Table 1, curricular matrix.

Table 1. Curricular matrix of the specialization course "Pedagogical Training of Professional Education in Health: Nursing"

\begin{tabular}{ll}
\hline Subjects & Hours \\
\hline Health and Education & 30 \\
Health and Education: Knowledge and Performance & 30 \\
Health and Education: Society and Culture & 30 \\
Health and Education: Work and Profession & 30 \\
Evaluating the Educational Practice in Health & 45 \\
Management in the Health Education Area & 60 \\
Research issues of the Health Education Area & 30 \\
Immersion in the Critical Pedagogy Practice & 45 \\
Planning a liberated Pedagogical Practice & 45 \\
Living a Meaningful Teaching Performance & 75 \\
\hline
\end{tabular}

Source:www.ufmg.br/ead/index.php/cursos/cursos-de-especializacao/formacao-pedagogica-de-educacao-profissional-na-saud e-enfermagem-cefpeps (2013)

It is necessary to record here the perception of the concern of the team of professionals responsible for this Course regarding the quality in the provision of health services to Brazilian population, when verifying that they have as challenge:

To expand the pedagogical qualification process in the health area, welcoming all the professionals of the area, contributing to the quality in the provision of health services to Brazilian population. Target audiences are higher level professionals in the health area - especially those that make up the structure of Primary Care of SUS and the Structuring Nuclei of Technical Schools of SUS ET-SUS. Understanding health and education as social practices, the course seeks to guarantee the student comprehension and analysis of reality, in its entirety, through the presentation of contents and proposition of activities in the form of themes that integrate theory and practice (CAED, 2017: online).

\section{Methodology}

It is a qualitative, exploratory and descriptive research, through a case study at UFMG, specifically in a Specialization Course offered in the distance modality by the Nursing School: "Pedagogical Training in Professional Education in the Health Area : Nursing “.

UFMG is a federal university located in Belo Horizonte city, located in Minas Gerais State - Brazil. The choice 
of the institution occurred due to its teaching referential for the whole country. In 2016, the UFMG was indicated by the "Folha" University Ranking (RUF) as the university which has the best quality teaching in the country. In the same year, UFMG was elected the seventh best Latin American university, according to Times Higher Education ranking. The course was chosen because it is the oldest Specialization Course of the Nursing School and also because it is the only one to be offered at a distance.

The corpus of the study was composed of 155 former students from 2011 to 2013 classes and, for the survey procedure, the chosen data collection instrument was a closed-ended questionnaire applied to the students, named respondents. The questionnaire was created in google docs and made available online to respondents. Regarding structure, the questionnaire was divided into two sections: the first questions (from one to five) were descriptive and dealt with the profile of respondents by age, sex, graduation area, place of residence and whether they were working in their professional area ( or if intend to work ). Questions six to fourteen were aimed at identifying the reasons for this course and its expectations. 155 e-mails were sent with the request for participation in the research and already with the questionnaire attached, and 44 questionnaires were answered, which corresponds to a $28.38 \%$ rate of return.

\section{Presentation and Discussion of Data}

\subsection{About Respondents' Profile}

The majority of participants (79.2\%) were female and $20.8 \%$ were male $(20.8 \%)$. The result found here is consistent with that presented by a survey conducted by the Federal Nursing Council (COFEN) in 2015, which showed that the Nursing team is predominantly female, comprising $84.6 \%$ of women. Also according to COFEN, even in the case of a female category, the presence of men is already becoming significant and the masculinization of the category is a trend.

Regarding age, the majority of respondents is comprised in the age groups of 31 to 35 years (43.9\%) and 36 to 40 years $(24.4 \%)$; in the age range between 25 and 30 years it is already a minor range with $17,1 \%$ of the sample and only $7.3 \%$ are over 46 years old. This result reflects Brazilian reality of Nursing professionals, according to COFEN Report: in 2010, Nursing professionals are concentrated in the age group of 26 to 55 years, most of them are in the range of 26 to 35 years, Which represents $35.98 \%$ of the total of these professionals.

Regarding the place of residence of the respondents, it was verified that the majority lives outside the metropolis, which can be observed in graph 1 . When the percentage of the respondents residing outside Belo Horizonte is added, it is $64.8 \%$, which represents the majority of the research participants. This fact proves that the EaD can be an alternative for professionals who are far from the metropolis. In addition, the results also showed that a significant portion (35.2\%) resides in Belo Horizonte and Metropolitan Region, where they would have access to face-to-face courses and, even so, opted to take a distance course. In this case, the main reason was the flexibility of schedules to take the course. 


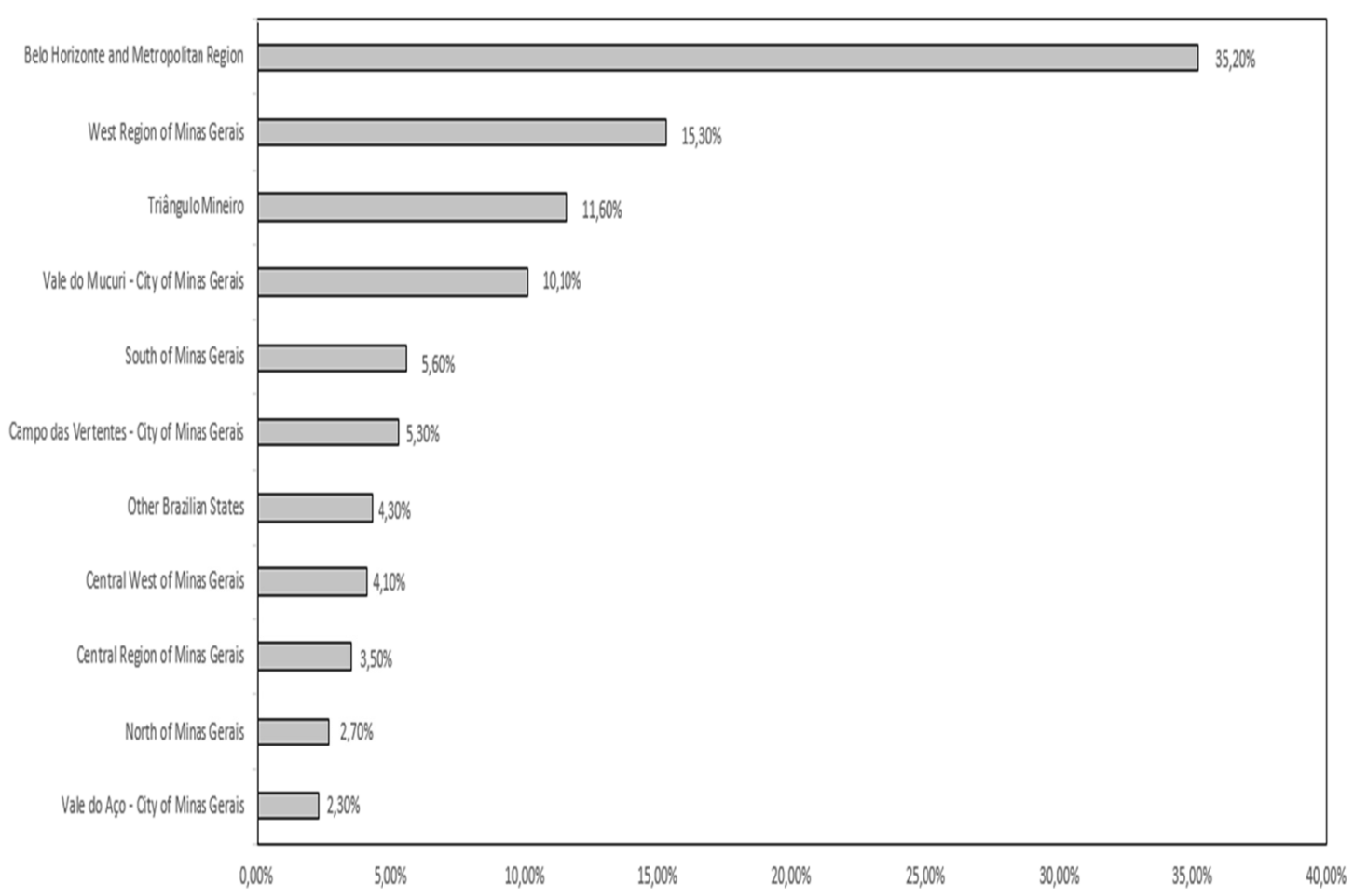

Figure 1. Place of respondents' residence (Source: Research Data)

All respondents are graduates in Nursing Being $90.2 \%$ are working in the area. Only $9.8 \%$ are not working in the area and among these, $80 \%$ want to work as a nurse. This result can be related to the fact that Nursing is a reference profession in the health area and also because it has several areas of activity, which integrates the provision of health services, such as: General Nursing, Geriatric Nursing, Medical-Surgical Nursing, Obstetric Nursing, Pediatric Nursing, Psychiatric Nursing, Rescue Nursing Public Health Nursing, Nursing Work, Teaching; Quality management, Project management and Clinical research.

\subsection{The Reasons for This Course and Its Expectations}

When questioned about the reasons for choosing a Distance Graduate, respondents should list answers 1 to 5 according to the degree of importance, and they could choose more than one option: 42 respondents pointed out that the major reason for the completion of the course was the desire for training and updating of knowledge.

This result confirms the thinking of Bock (1999), who advocates that one of the motivations for a person to take a distance course is the need for continuity in their studies.

Five respondents considered the enrichment of the curriculum and creation and expansion of the network contacts, a level 4 of relevance for the course. Once again, the result converges to COFEN's 2015 survey, which reveals that the desire to qualify is a longing for the nursing professional. This result also ratifies Moran's (2002) ideas about continuing education, in which professionals are in constant formation, learning and joining the new information with their own practical experiences.

Another aspect analyzed was the reason that led them to take a distance course. They were asked to list responses from 1 to 5 according to the degree of relevance, and they could choose more than one option. The responses were: 35 considered that the flexibility of the schedule is the factor that contributed the most to the course choice, 28 respondents considered the study rhythm to be defined by them as a factor of importance; 21 responded that the classroom can be anywhere they feel comfortable; 22 signaled that in the city where they live there is no course that he wanted in-class mode. These results are in line with the observations of Quaglia et. al. (2015:1100) who consider that the "EaD is an instrument that can add (in) training to the health agenda, regardless of their place of work", providing a new concept of learning.

\subsection{The Difficulties Found out During the Course}

Regarding the difficulties found, $30.2 \%$ of the respondents reported that they did not find any difficulties during 
the course. The other respondents reported that they had difficulties during the course, the main one being time management. They also stated that one of the reasons for this difficulty is the activity that involves online discussions. For them, this activity often takes a lot of time, since it requires deeper analysis to the detriment of the various contributions in online classrooms always open. Also, this lack of time is critical for many students who claim to be overworked, unable to balance time with obligations, training and family.

Already $60 \%$ of the respondents showed that they had knowledge about the methodology used. For them, this was due to the experience of teachers who work in the area they teach. The $40 \%$ who claimed to have difficulty with the methodology of the course attributed this difficulty to the lack of stimulation of some tutors.

Regarding the digital tools of the virtual learning environment, $60 \%$ of the respondents stated that they had no difficulties in using them. About the contents of the subjects, $9.3 \%$ of the respondents said they were tiring, with a lot of theory and extensive exercises. However, they also acknowledge that the reason may be their own difficulties in developing some tasks or even finding the information in the virtual learning environment.

Finally, in a general way, according to the respondents, the main difficulties or obstacles found in EaD in relation to the disciplines were:

- Many content to study in a short time.

- Many activities at the same time, therefore this is a burden on who worked at more than one place (which is very common in the Nursing area).

- Very theoretical content, sometimes the disciplines became tiresome, as a suggestion it could be more practice and could be used more examples of real cases in the course (of the nurse's daily life).

- Difficulties of the displacement to the poles, which sometimes didn't stay at the student's city.

- Sometimes the digital tools, computers and the internet didn't work well. Then, the virtual learning platform, in this case Moodle, was locked and there wasn't another way to post the activities.

- The meeting with the tutor face-to-face just happened once a month.

\section{Has the course met your professional needs?}

Most respondents (73.2\%) stated that yes, a small portion (2.4\%) replied that they did not, and $24.4 \%$ stated that perhaps. This result is consistent with the answers to the following question posed to the former students: Does the postgraduate Program help in the career of the health professional? $92.7 \%$ of the respondents said yes, those who said that it was not the same part of the previous question (2.4\%) and $4.9 \%$ state that it might help.

In relation to the main contribution of the course, five options were analyzed: Obtaining a postgraduate diploma; the acquisition of general culture; Acquisition of professional training; The acquisition of theoretical training; And, Better prospects for material gains. Respondents should mark in each option the degree of relevance to their training. It was verified that the respondents consider the five important options when performing a distance graduate. However, there was a significant emphasis on the acquisition of vocational training, followed by the acquisition of theoretical training. This result demonstrates the concern of these professionals regarding their training to better serve the population and reinforces the importance of the adoption of programs of permanent education for professionals in this area, as Marques et al. (2012).

To find out the criteria used by the respondents in choosing the institution for the course, eight options were available: Teachers and tutors need to be qualified; The course must be accredited with the MEC; Adequate structure such as video tutorials and online tutoring; The institution must count on a presence pole of good infrastructure; Access to physical and virtual libraries; Request of the company where working for; Indication of a co-worker; And, The institution must have a good channel of communication among the students, in which respondents should also mark the degree of importance of each one of them.

And the most important criterion is that the course must be accredited with the MEC. It was clear that respondents are concerned about the quality of the course that will be offered and, consequently, with the qualification resulting from this training to better serve the Brazilian population, which meets the concern of the team of professionals responsible for this course that seeks to ensure students' understanding and analysis of reality with a focus on theory and practice (CAED, 2017).

It is worth mentioning that, in the perception of the respondents, there was little relevance in relation to the request of the company where they work to do a postgraduate Course. One of the reasons for this may be the concern of companies to release employees to attend courses. Barboza (2016) points out that, nurses almost have, for the most part, difficulties in studying mainly because of the working shifts. 
Facing this reality, these professionals have sought in the EaD courses a way to continue their studies, because as emphasized by Moran (2002), the EaD does not offer space-time limitations that, for health professionals, is an excellent opportunity for learning and qualification.

\section{Conclusion}

In this research, it was verified the perceptions of health professionals seeking Lato sensu Postgraduate Courses offered at a distance to be trained. The Pedagogical Training Course in Professional Education in the Health Area: Nursing was chosen to study.

It should be mentioned that Nursing is a reference profession in the health area and that it has several areas of action, a fact proven in this research, since $90.2 \%$ of the respondents are working in the area. And yet, the concerns of these professionals in relation to their continued education to better serve the population, which might be desirable.

This concern has resulted in the search for quality courses and, therefore, the participants of this research chose an accredited course with the MEC and a university that has a great credibility. Therefore, the interest of nurses to have a qualification or a continuing education reinforces the importance of the adoption of programs of permanent education for the professionals of this area.

However, there are many barriers that prevent them from continuing their studies, such as the lack of time that is critical for many who claim to be overworked, unable to balance time with their duties, training and family. And to solve this problem, the respondents have seen in distance education the possibility of re-studying.

It was also noticed that during the distance course, the greatest difficulty showed by the students was the administration of time, even it being a course in the EAD modality. Often the tutors needed to extend the time to deliver the activities on the Moodle platform so that the students could post the activities later, since the deadline in the system was controlled by the tutors.

Thus, the present study showed that EaD can contribute to health in Brazil, allowing professionals in this area who are far from the metropolises and / or who do not have time to attend an in-class course, mainly due to the shift of work, to take courses of training and, therefore, have access to new knowledge and improving their professional performance and who might enjoy this reality are the users who receive a quality health care.

Regarding to the research limitations, two points are highlighted: The use of a closed questionnaire, which, unlike the open questionnaire, did not allow us to explore all the possible answers regarding the issues raised and the difficulty to obtain the participation of the respondents, mainly due to the questionnaire has been made available online, which is convenient for the respondent, since the respondent can answer the questionnaire in the way that is most convenient, as Malhota (2006) \& Aaker, Kumar \& Day (2007) point out.

As a suggestion of future research, two possibilities should be highlighted: a study on the opinion of professionals from other areas applied in other institutions that practice $\mathrm{EaD}$, and a comparison between this research and the one suggested verifying if the same degree of perception found in Nursing courses is found in courses in other areas.

\section{References}

Aaker, D. A., \& Kumar, V., \& Day, G. S. (2007). Pesquisa de marketing (2nd ed.). São Paulo: Atlas.

ABED (Associação Brasileira de Educação a Distância). (2014). Censo EAD.BR: relatório analítico da $\begin{array}{lllll}\text { aprendizagem a distância no Brasil. } & \text { Retrieved } & \text { from }\end{array}$ http://www.abed.org.br/censoead2014/CensoEAD2014_portugues.pdf

ABED (Associação Brasileira de Educação a Distância). (2015). Censo EAD.BR: relatório analítico da $\begin{array}{lllll}\text { aprendizagem } & \text { a } & \text { distância no } & \text { Brasil. } & \text { Retrieved }\end{array}$ http://abed.org.br/arquivos/Censo_EAD_2015_POR.pdf

Barbosa, M. A., Medeiros, M., Prado, M. A., Bachion, M. M., \& Brasil, V. V. (2004). Reflexões sobre o trabalho do enfermeiro em saúde coletiva. Revista Eletrônica de Enfermagem, 6(1), 9-15. https://doi.org/10.5216/ree.v6i1.804

Barboza, F. T. (2016). Palavra de Quem Entende: A importância da Enfermagem no contexto nacional. Blog Gran Cursos Online. Retrieved from http://blog.grancursosonline.com.br/a-importancia-da-enfermagem-nocontexto-nacional/

Batista, K. B. C., \& Gonçalves, O. S. J. (2011). Formação dos Profissionais de Saúde para o SUS: Significado e cuidado. Saúde Soc. São Paulo, 20(4), 884-899. https://doi.org/10.1590/S0104-12902011000400007 
Bisol, C. A. (2010). Ciberespaço: terceiro elemento na relação ensinante/aprendente. In: VALENTINI, Carla Beatris; SOARES, Eliana Maria do Sacramento (Orgs.). Aprendizagem em ambientes virtuais: Compartilhando ideias e construindo cenários (2nd ed.). Caxias do Sul: Educs, 1, 21-32.

Bock, A. M. B. (1999). Psicologias: Uma introdução ao estudo de Psicologia (13th ed.). São Paulo: Saraiva.

Brasil. (1988). Constituição da República Federativa do Brasil. Brasília: Senado Federal. Retrieved from

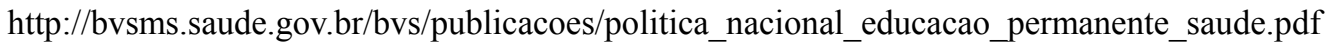

Brasil. (2005). Ministério da Educação. Decreto n. 5 622, de 19 de dezembro de 2005. Regulamenta o Art. 80 da Lei n. 9 394, de 20 de dezembro de 1996. Retrieved from http://www.planalto.gov.br/ccivil_03/_Ato20042006/2005/decreto/D5622.htm

Brasil. (2014). Ministério da Educação. Cursos de Pós-Graduação Lato Sensu a Distância. Retrieved from http://portal.mec.gov.br/pet/180-estudantes-108009469/pos-graduacao500454045/12776-cursos-de-pos-gra duacao-lato-sensu-a-distancia

CAED (Centro de Apoio a Educação da Distância). (2017). Formação Pedagógica de Educação Profissional na Saúde: Enfermagem (CEFPEPS). Retrieved from https://www.ufmg.br/ead/index.php/cursos/cursos-deespecializacao/formacao-pedagogica-de-educacao-profissional-na-saude-enfermagem-cefpeps/

Ceccim, R. (2005). Educação permanente em saúde: desafio ambicioso e necessário. Interface-Comunic, Saúde, Educ, 9(16), 161-177. https://doi.org/10.1590/S1414-32832005000100013

Ceccim, R., \& Ferla, A. A. (2016). Educação Permanente em Saúde. Retrieved from http://www.epsjv.fiocruz.br/dicionario/verbetes/edupersau.html

COFEN (Conselho Federal de Enfermagem). (2001). Comissão de Business intelligence Retrieved from http://www.cofen.gov.br/wp-content/uploads/2012/03/pesquisaprofissionais.pdf

COFEN (Conselho Federal de Enfermagem). (2015). Pesquisa inédita traça perfil da enfermagem. Retrieved from http://www.cofen.gov.br/pesquisa-inedita-traca-perfil-da-enfermagem_31258.html

Folha de São Paulo. (2017). RUF. Ranking Universitário Folha. Retrieved from http://ruf.folha.uol.com.br/

Lopes, A. M., \& GROSSI, M. G. R. (2014). Ações pedagógicas do curso técnico a distância da rede e -Tec Brasil CEFET-MG e as concepções de Paulo Freire. Revista Intersecções, 14(3), 53-72.

Malhotra, N. (2006). Pesquisa de marketing: uma orientação aplicada (4th ed.). Porto Alegre: Bookman.

Marques, A. J. S., Miranda, J. B. M., Moreira, L., M. C., \& Riani, R. R. (2012). O programa via saúde na capacitação de profissionais de saúde em Minas Gerais. Pretexto, 13(2), 91-96. http://dx.doi.org/10.21714/pretexto.v13i2.1169

Moore, M. G., \& Kearsley, G. (2007). Educação a distância: Uma visão integrada. São Paulo: Thomson Learning.

Moran, J. (2002). O que é educação a distância. Retrieved from http://www2.eca.usp.br/moran/wpcontent/uploads/2013/12/dist.pdf

Nunes, I. B. (1998). Noções de educação a distância. Retrieved from http://www.educadores.diaadia.pr.gov.br/arquivos/File/2010/artigos_teses/EAD/NOCOESEAD.PDF

Peres, A. M., \& Ciampone, M. H. T. (2004). Cursos sequenciais e os novos profissionais na área de saúde: oportunidade ou ilusão? Educar, Curitiba, 24, 259-268, 2004. https://doi.org/10.1590/0104-4060.360

Quaglia, I., \& Oliveira, A., \& Velho, A. P. M. (2015). Capacitação em saúde na educação a distância (EaD): uma análise sistemática do conteúdo. Saúde e Pesquisa, 8, Edição Especial, 103-112.

Times Higher Education. (2017). Latin America University Rankings 2016. Retrieved from https://www.timeshighereducation.com/

\section{Copyrights}

Copyright for this article is retained by the author(s), with first publication rights granted to the journal.

This is an open-access article distributed under the terms and conditions of the Creative Commons Attribution license (http://creativecommons.org/licenses/by/4.0/). 